Article

\title{
Power Relationship in the Governance of Regional Tourism Organizations in Brazil
}

\author{
Calidon Costa Conceição, Francisco Antonio Dos Anjos * $\mathbb{D}$ and Sara Joana Gadotti dos Anjos $\mathbb{D}$
}

Tourism and Hotels Management, Univesidade do Vale do Itajaí, Balneário Camboriú 88337 300, Brazil; calidoncosta@gmail.com (C.C.C.); sara@univali.br (S.J.G.d.A.)

* Correspondence: anjos@univali.br

Received: 29 March 2019; Accepted: 20 May 2019; Published: 30 May 2019

Abstract: Objective: The development of tourism is one the main objectives of managers seeking a greater competitive advantage for destinations. To achieve this objective, the political-institutional structure related to public and private organizations involved in the Brazilian scenario of tourism activities deliberately operate in the format of Regional Tourism Organizations-RTOs, which started in 2004. In this context, the aim of this study arose, which is to analyze the power relations of Regional Tourism Organizations of tourist regions. Design/Methodology: This research adopted a qualitative and quantitative approach, with data collection through documents, laws, reports and information about the RTOs and questionnaires in forms applied to 27 representatives of the public sector, 14 representatives of private sector and six representatives of the third sector, from a total population of 89 active members of the Regional Tourism Organizations: Costa Verde e Mar (state of Santa Catarina), Hortênsias (state of Rio Grande do Sul), and Costa das Dunas (state of Rio Grande do Norte). During the application of the forms, interviews were carried out, totaling 47 interviews with members of the RTOs. Quantitative analyses were generated by mean, mode, absolute and relative frequencies, multiple responses and dispersion graph, with the use of descriptive analyses. The qualitative analyses involving documents were descriptive, and those involving oral information were carried out using analysis of content of Bardin (1977). The different methods that were used in an interrelated manner and helped in the analysis of the data coming from the application of forms (quantitative), official documents (laws/decrees, regulations and statutes), and interviews with actors of the regional tourism organizations (qualitative), enabled the measurement of the effectiveness of the process of management of RTOs in relation to the dimension Power Relationship and the variables analyzed Representativeness, Harmony, Trust and Decision-Making Power. Results: As a result, it was seen that the regional tourism organizations of the tourist regions operate in an effective manner in the public or private sectors and that they involve the management of shared practices by the regional tourism organizations in the destinations studied in terms of representativeness, harmony, trust and decision-making power. Novelty/Value: This research theoretically deepened for the academy the theme of regional governance and power relationship between public and private actors in tourism who are important for the competitive performance of a tourist destination. It also analyzes how the management and governance of regional tourism organizations behaves in terms of power relationships.

Keywords: regional tourism organization; power relationship; Brazil; Costa Verde e Mar; Tourism Region of Hortênsias; Costa das Dunas Tourism Center

\section{Introduction}

Regional organization is a form of policy that brings together actors from the public and private sectors and from the third sector, who work together to maximize resolutions in a cooperative manner 
for the development of the region and to minimize actions that do not meet the desires and wishes of its actors and civil society [1]. The structure of the organization is an institutional arrangement that develops political processes of implementation, and formulates political objectives coordinated by its various actors [2].

Regional organization, for Araújo and Simonian [3] is an agreement that takes place between its public and private actors, which allows the identification of actions of different natures, helping the development and promotion of the region in an integrated way. According to Bramwell and Lane [4], it cannot be seen in isolation, because it manages the society relationship, which includes social groups seeking to influence the governance process. Thus, regional tourism organization refers to the interaction between tourism and governance, which is referred to by Oliveira [5] as a relationship that occurs between a set of actors who are engaged in planning, managing and controlling the tourism activity.

In this context, this article presents the theme of regional tourism organization as a central issue, making possible to understand the existing power relations among its actors, focusing on three regional tourism organizations in Brazil—Costa Verde e Mar-CVM (in Santa Catarina), Hortênsias—RT (in Rio Grande do Sul) and Costa das Dunas-PCD (Rio Grande do Norte). This study made it possible to-analyze the power relations between the actors of the regional tourism organizations of the Brazilian tourist regions.

The thematic cutting occurred through the need to understand the power relations between the actors and entities of regional tourism governance, since from the decisions made, their impacts fall on all members, regardless of the positioning. Understanding power relations is fundamental for evaluating and proposing solutions to the conflicts that are present in regional tourism governance (Bramwell and Lane, 2011). The interrelationships between public power, private sector and third sector need to be duly mediated so that the actors act cooperatively, whose perspectives should be tied to the participatory decisions and to the power relations of its members in the process of growth and development of the tourist regions.

The process of regionalization in Brazil occurred with a government incentive, starting in 2004, when the Plano de Regionalização do Turismo (PRT) "Roteiros do Brasil" (Roteiros do Brasil" Tourism Regionalization Plan) was launched, pointing out in its third operational module regional tourism organizations, and procedures and references on the formalization and institutionalization of the Regional Tourism Organizations (RTOs) in Brazil. In this context, the central problem of this research arises: How did the power relations between governance actors in Brazilian tourist regions consolidate since its implementation, and what impacts did the process generate in the organization of the regional tourism organization?

Oliveira and Pisa [6] understand that regional tourism organization is a system of formal and informal rules (norms, procedures, customs, etc.) that establishes the relationship between tourist actors (public authorities, private initiative and social actors). This study aims to understand the formal organization, which is established in tourist regions (regional organizations, tourist centers, tourist itineraries and tourism forums).

In an attempt to understand the regional tourism organization and its process of interaction and cooperation, linked to power relations among its actors, this research is relevant to the theme for the academic and managerial fields of tourism, for its assertive and propositional contribution in presenting elements of analysis of regional tourism organizations.

In the following sections, a theoretical review of the academic contributions on tourism governance and power relations will be presented, with a focus on governance actors. This is followed by the methodology, which presents the procedures that were developed to seek to an answer the objective as well as the matrix of base constructs of the performed analysis. The two sections that follow present the results and implications of the analysis performed. 


\section{Regional Tourism Organization}

For Trentin, "governance is understood as a political paradigm in which traditional forms of government are opposed" ([7], p. 651), since it is not necessarily attributed exclusively to public or private sectors and it can be used in both or only by one of them. Olsson [8] highlights that governance is a set of activities that regardless of whom performs it, whether formal or informal, must be shared and accepted by its actors. Rhodes ([9], p. 51) says that it is a system that allows for an "interdependence between organizations; the continued interaction between members of a network; interactions that give space for trust, with negotiated rules; significant autonomy from the state, so that the formal aspects of governance can reach the political objectives, which are surrounded by a referential basis that is known by all its members".

Kooiman [10] contributes by ensuring that governance is based on a multiplicity of actors, with interdependence, with clear and shared objectives, presenting borders between the public, private and the spheres that are considered associative, with a multiplicity of forms of intervention, actions and controls.

It is common for governance to realize that its concepts move towards the understanding that there must be consensus in the decisions of its representatives and that its planning and actions are decided by all members. Cassiolato and Lastres [11] comment that governance is the form by which individuals as well as organizations, regardless of whether they are public or private, manage their common problems, their interests cannot be individual, they are always collective, and governance can be formally or informally established.

Regional tourism organization is conceptualized by Vera Rebollo ([12], p. 346) as being part of the "public-private decision-making processes, whose objective is to improve the management of the conflicts that are inevitably provoked by the activity at the destination. Tourism governance would mean going one step further in tourism government."

Regional tourism organization is a management model embedded in social relations, in which its actors participate in joint decision-making in order to provide the development of tourism activities in the region they involve. In this sense, the actors, by accepting the bonds established by the management of regional tourism organizations, enable greater involvement with the established partnerships, involving the integration and cooperation of all its actors, and being committed to discuss and carry out what may be proposed by the organizations through their management models [1].

Regional tourism organization, as an integral part of collective management, is not only a simple formation of a partnership, but it is also a union for the resolution of conflicts of interest that may arise within the framework of governance. The purpose is to make the participation of its actors, i.e., stakeholders directly involved in tourism, become intertwined with the stages of creation and development of public policies for their sector (Costa; Carvalho, [13], p. 44).

The management of regional tourism organizations is currently popular, as it directly relates to its social actors, with vertices that present characteristics that aid in the engendering of several dimensions of tourism governance. Beaumont and Dredge ([14], p. 10) present dimensions called tourist effectiveness that are:

Constructive communication and committed communities, transparency and accountability, vision and leadership; acceptance of diversity and pursuit of equity and inclusion; development of knowledge, learning and shared experience, as well as roles and responsibilities of the participants, as well as clear structures and operational processes of the network. According to their perspective, the effectiveness of tourism governance to achieve the purposes of their stakeholders depends on the effectiveness of institutional structures and processes; relational resources and skill set.

There have been changes to the concept, because for some time governance was an exclusive concern of the government, and the government should coordinate public policies directed to the management of the tourism. Gorni and Dreher [15] state that regional organizations cannot only be based on management issues that are considered traditional, but must also address new ways of 
understanding the form of relationship that may arise, in which collective networks can be seen as a follow up process in which the dialogues must be controlled, and for this to happen an interdisciplinary discussion focused on social relations is necessary, since these dialogues may appear in the agendas of regional organizations.

\section{Power Relationships in Regional Organizations}

The power relationship used in this study refers to four categories of analysis that are considered essential for the understanding of the tourist regions of the research. The categories listed were:

1. Representativeness between public, private and third sectors in regional tourism organizations;

2. Harmonic and effective relationships between private and public actors of regional tourism organizations;

3. Trust relationship among members of regional tourism organizations;

4. Decision-Making Power in proposals and validations of actions of regional tourism organizations (Table 1).

Table 1. Dimension Power Relationship, categories and variables.

\begin{tabular}{lll}
\hline \multicolumn{1}{c}{ Categories } & \multicolumn{1}{c}{ Variables } & \multicolumn{1}{c}{ Authors } \\
\hline $\begin{array}{l}\text { Category 1-Representativeness among } \\
\text { public, private and third sectors }\end{array}$ & Cooperation practices; & $\begin{array}{l}\text { Dreher and Salini [16], Nóbrega [17], } \\
\text { Araújo and Dredge [18], Lefebvre [19], } \\
\text { Tomio and Schimidt [20], and Valente, } \\
\text { Dredge, and Lohmann [21]. }\end{array}$ \\
\hline $\begin{array}{l}\text { Category 2-Harmonic and effective } \\
\text { relationships between private and public } \\
\text { actors of regional tourism organizations }\end{array}$ & Interaction; Harmony & $\begin{array}{l}\text { Zahra [22], Cunha and Mazaro [23], } \\
\text { Meneghel and Tomazzoni [24]. }\end{array}$ \\
\hline $\begin{array}{l}\text { Category 3-Trust relationship among } \\
\text { members of regional tourism } \\
\text { organizations }\end{array}$ & Trust; Engagement Level & $\begin{array}{l}\text { Rovere [25], Pechlaner, Volgger and } \\
\text { Herntrei [26], Tomio and Schimidt [20], } \\
\text { Nóbrega [17]. }\end{array}$ \\
\hline $\begin{array}{l}\text { Category 4-Decision-Making Power in } \\
\text { proposals and validations of actions of } \\
\text { regional tourism organizations }\end{array}$ & Decisions by common agreement & $\begin{array}{l}\text { Virginio, Delgado and Fortes [27], } \\
\text { Duran [28], Gorni and Dreher [29] }\end{array}$ \\
\hline & Source: created by the authors. &
\end{tabular}

Category 1 portrays the representativeness between public, private and third sectors in regional tourism organizations. Dreher and Salini [16]; Nóbrega [17], Araújo and Dredge [18], Lefebvre [18], Tomio and Schimidt [20] argue that relations between public and private sectors should go hand-in-hand, so that cooperation among those involved will benefit all members of society. If there is an imbalance in the representativeness, there is a risk that there will be a direction of actions to favor only one of the powers, and the interest of walking together and deciding on the management, process, monitoring and evaluation of the activities inherent to the actors of the governance disappears.

Harmonic and effective relationships between the private and public actors of regional tourism organizations are established in Category 2. The existence of a healthy interaction between the actors of the same group requires harmony among those involved. The harmonic relationship does not mean that there can be no debate for the improvement of the regional organization or about actions to be developed, but essentially, what should be present is the interest of the society and of those directly and indirectly involved in the tourist activity of the region (Luz et al. [30]; Zahra [21]; Cunha and Mazaro, 2011 [22]; Meneghel and Tomazzoni, 2012 [23]; Valente, Dredge, and Lohmann [20]).

In Category 3, priority is given to the trust relationship among the members of regional tourism organizations. Nóbrega [17] asserts that trust is one of the main factors required to enable actions and perceptions to be implemented in public environments that are responsible for encouraging the regional development of tourism. In this sense, Rovere [24] suggests an ascending scheme, with four levels: (1) recognition, (2) knowledge, (3) collaboration, (4) cooperation, and (5) association, providing 
an opportunity to understand the level of engagement of actors and organizations. Scharpf (1992); Rovere [24] Pechlaner, Volgger and Herntrei [25]; Tomio and Schimidt [19] point out that the capacity of trust that occurs within organizations must involve their members in the most diverse forms, whose intention is to make the entity more and more collaborative through the actions developed by its actors, making them capable of creating and implementing collective and cooperative policies.

Decision-making power in the proposal and validation of regional tourism organizations' actions are established in Category 4. The relationship of decision-making and the proposal or validation of actions is necessary for the existence of decisions in common agreement between the actors involved, so that the gears of the organization management can work. The aspirations must be to achieve better joint results, both in the proposals to be made and in their validation for actions. The decisions made by the RTOs' actors should be to improve tourism activity in the region, improving the quality of life of those directly and indirectly involved with regional tourism organization (Rover, 2007 [31]; Virginio, Delgado and Fortes, 2011 [27]; Duran, 2013 [28]; Gorni and Dreher, 2011 [15]).

The categories were grouped, thus forming the dimension called Power Relationship, which contributed to clarify the relations of the regional tourism organizations on aspects that dealt with trust, harmony, power of decision and representativeness among the powers. Following the oral information provided by the interviewees, it was observed that the categories brought elements that supported the understanding of the tourism regional organizations, elements arranged in involvement in the creation and execution of the actions, in the cooperative involvement and in the balance in representativeness.

This dimension demonstrates how the power relationship between members of the organization works, since it is significant to understand how this interrelationship occurs, as, in a pragmatic way, they get involved and are intertwined to obtain joint results, even though an imbalance can be seen in RTOs' management, in the number of members and in the representativeness of one power over another.

\section{Methodology}

\subsection{Sample Size and Data Collection}

This applied research adopted a qualitative and quantitative approach. The results were obtained through the application of questionnaires with public and private actors, effective members of regional tourism organizations of the tourist regions of Costa Verde e Mar (Santa Catarina), Tourist Region of Hortênsias (Rio Grande do Sul) and Costa das Dunas Tourism Center (Rio Grande do Norte), located in Brazil.

The tourist regions of this research were selected based on certain factors: (1) the regions are consolidated in the tourism scenario at local, regional, national and international levels; (2) the regions have formally constituted RTOs, according to the Brazilian Ministry of Tourism; (3) the regions are important in terms of tourism for their respective states; (4) the regions can be analyzed in a number of ways that make it possible to understand RTOs; (5) the regions have data that can contribute to the characterization of RTOs.

The selected tourist regions are representative within their states, and consequently Brazil, through various contexts, ranging from tourism, social, economic, environmental and cultural contexts, to the significance of the scenario in the generation of employment and income, the ability to receive visitors, tourism infrastructure of their destinations and attractions, as well as contributing to the development of the regions in which they are located.

For national tourism, the three regions selected for this study are considered representative and significant for national tourism, since destinations within the regions are recognized in Brazil, such as Gramado in the Region of Hortênsias, which is one of the best known destinations to visit mountains in Brazil; Balneário Camboriú, the main coastal destination of southern Brazil; and Natal, one of the main beach destinations of the Brazilian Northeast region. 
The destinations mentioned above are inductors of regional development recognized by the MTur (Ministry of Tourism), a policy created in 2009 with the purpose of corroborating with the development of tourism of other destinations in the same regions.

The tourist region of Costa Verde e Mar-SC comprises 11 municipalities, more noteworthy Balneário Camboriú (A), Bombinhas (A), Itajaí (B), Itapema (B) and Penha (B). The region of Hortênsias-RS is formed by five municipalities, with emphasis on Gramado (A), Canela (B) and Nova Petrópolis (B). The Costa das Dunas-RN region is formed by 16 municipalities, the main ones are Natal (A), São Miguel do Gostoso (B) and Tibau do Sul (B). Categories A and B refer to the highest classifications of tourist municipalities in Brazil, declared by the Tourism Map in Brazil from 2017-2019 of the Ministry of Tourism, on a scale from A to E.

Costa Verde e Mar became a reference in terms of diversity on the practice of tourism [32], a region considered important due to its diversified segmentation, and mainly due to its destinations and attractions.

The Tourism Region of Hortênsias (TRH) is considered a very relevant region for the state of Rio Grande do Sul in relation to the tourist activity, representing about $30 \%$ of the tourists entering the State, with the highest revenues of the tourism sector [33].

The Costa das Dunas region is the main receiving region of Rio Grande do Norte, with a strong tourist appeal for natural and coastal landscapes. The use of its natural environment as tourist attraction grants the visitor contact with its coastline and warm waters, cliffs, dunes and lagoons, with sun and beach tourism as its main tourist segment [29].

Data collection procedures involved three phases:

1. The first phase was on-site data collection, using a form and interviews applied to the effective members of the regional tourism organizations studied in this research. Intentional probabilistic sampling was used. The application of the form for quantitative data reached the managers of the three regions analyzed. The qualitative approach was based on the oral communications presented by the interviewees during the application of the form, which, in addition to pointing out their considerations on the RTO, indicated the existing documents for each region, such as laws/decrees, regulations and statutes.

2. A second phase took place in an entwined way, using documentary research that was integrated with the data collected by the form and the interview.

The field research was carried out in the regions of Costa Verde e Mar (Santa Catarina), Tourist Region of Hostênsias (Rio Grande do Sul) and Tourist center Costa das Dunas Coast (Rio Grande do Norte), whose target population were effective representatives of Regional Tourism Organizations (public, private and third sectors) (Table 2).

Table 2. Effective representatives of the Regional Tourism Organizations.

\begin{tabular}{cccc}
\hline Regions & Sector & Population & Interviewees \\
\hline \multirow{3}{*}{ Costa Verde e Mar-SC } & Public & 13 & 10 \\
& Private & 09 & 05 \\
& Third Sector & 05 & 01 \\
\hline \multirow{3}{*}{ Tourism Region of Hortênsias-RS } & Public & 12 & 10 \\
& Private & 13 & 07 \\
& Third Sector & 07 & 01 \\
\hline \multirow{2}{*}{ Costa das Dunas Tourist Center-RN } & Public & 12 & 06 \\
& Private & 12 & 05 \\
& Third Sector & 06 & 02 \\
\hline TOTAL & & 89 & 47 \\
\hline
\end{tabular}

Source: created by the authors (2019). 
From a total of 89 managers from the analyzed regions, the sample was 47 interviewees, $51.83 \%$ of the universe, characterizing the existence of a valid sample [30].

\subsection{Survey Tools and Data Analyses}

The technique used to collect the data consisted of a structured questionnaire in a form with the objective of analyzing the power relationships of the regional tourism organizations of the tourist regions of Costa Verde e Mar-SC, Hortênsias-RS and Costa das RN, Brazil.

The form based on the theoretical framework presents four sections: Profile of the interviewee (gender, schooling, position and time in the regional tourism organization) four questions; the four variables of the construct Power Relationship: C1-Representativeness, C2-Harmony; C3-Trust; and C4-Decision Power, with three questions for each variable, totaling 16 questions (Table 3).

Table 3. Constructs and variables of the survey tool, dimension.

\begin{tabular}{|c|c|c|}
\hline Categories & Variables & Authors \\
\hline $\begin{array}{c}\text { Category 1- } \\
\text { Representativeness }\end{array}$ & $\begin{array}{l}\text { C1.1. Parity of number of members, so that there } \\
\text { is balance in decision-making. } \\
\text { C1.2. Same voting and decision-making power in } \\
\text { actions to be taken. } \\
\text { C1.3. Usually decisions are taken by one of the } \\
\text { powers only in relation to activities developed by } \\
\text { the regional tourism organization. }\end{array}$ & $\begin{array}{l}\text { Dreher and Salini [16], Nóbrega [17], } \\
\text { Araújo and Dredge [18], Lefebvre } \\
\text { [19], Tomio and Schimidt [20], and } \\
\text { Valente, Dredge, and Lohmann [21]. }\end{array}$ \\
\hline $\begin{array}{l}\text { Category } 2 \text { - Harmonic } \\
\text { and effective relationships } \\
\text { among actors }\end{array}$ & $\begin{array}{l}\text { C2.1. Designing of projects developed by the } \\
\text { regional tourism organization shows effective } \\
\text { and harmonic interaction among members. } \\
\text { C2.2. Decisions are made in a harmonic way } \\
\text { C2.3. Meetings take place periodically }\end{array}$ & $\begin{array}{l}\text { Zahra [22], Cunha and Mazaro [23], } \\
\text { Meneghel and Tomazzoni [24]. }\end{array}$ \\
\hline $\begin{array}{l}\text { Category } 3-\text { Trust } \\
\text { relationship }\end{array}$ & $\begin{array}{l}\text { C3.1. Information presented in relation to actions } \\
\text { carried out by the regional tourism organization } \\
\text { is accepted with no questioning by members. } \\
\text { C3.2. The representative who are part of the } \\
\text { group(s) and who carry out assessments of } \\
\text { activities developed by the regional tourism } \\
\text { organization are totally trusted by its members. } \\
\text { C3.3. The relationship among actors and their } \\
\text { activities take place in a confident manner. }\end{array}$ & $\begin{array}{l}\text { Rovere [25], Pechlaner, Volgger and } \\
\text { Herntrei [26], Tomio and Schimidt } \\
\text { [20], Nóbrega [17]. }\end{array}$ \\
\hline $\begin{array}{l}\text { Category } 4-\text { Decision } \\
\text { power in proposals and } \\
\text { validation of actions. }\end{array}$ & $\begin{array}{l}\text { C4.1. Participation of private actors in } \\
\text { decision-making taken by the regional tourism } \\
\text { organization in relation to actions, monitoring, } \\
\text { and assessment of management are carried out by } \\
\text { private and third sectors' actors. } \\
\text { C4.2. Participation of public actors in } \\
\text { decision-making taken by the regional tourism } \\
\text { organization in relation to actions, monitoring, } \\
\text { and assessment of management are carried out by } \\
\text { public sector actors. } \\
\text { C4.3. There is evident greater autonomy from one } \\
\text { actor in detriment to others (public, private and } \\
\text { third sectors). }\end{array}$ & $\begin{array}{l}\text { Virginio, Delgado and Fortes [27], } \\
\text { Duran [28], Gorni and Dreher [15]. }\end{array}$ \\
\hline
\end{tabular}

Source: created by the authors (2019).

The questions presented in the questionnaire were derived from the variables shown in Table 3 , which presents a synthesis of the theoretical contributions on the subject, allowing its use in the field research, in which its results were treated and analyzed, bringing pertinent and factual results.

The questions were arranged in a seven-point Likert scale (from totally disagree to totally agree or from not at all to totally) [34].

The quantitative treatment was performed using the version 25 of the IBM SPSS STATISTICS software. The analyses carried out were of mode and median, multiple case classifications, absolute and relative frequencies and dispersion graphs. 
Data from the observations and the notes taken as oral information provided by the effective members of the regional tourism organizations during the application of the forms were used for the qualitative analyses, as well as the information collected in the public documents of the regional tourism organizations (laws/decrees, regulations and statutes), which supported the documentary analysis.

For the quantitative part of the research, the analyses were carried out based on the descriptive statistical analysis and for the qualitative part, Bardin's content analysis [35] of the naturally provided and raised information and analysis of the official documents of the governances (qualitative).

The attempt to understand the effectiveness of management makes it possible to understand the arrangement of the organization, how to improve or consolidate organizational processes, power relationships, information and actions and their results. The model is composed of categories and analytical dimensions that make it possible to analyze regional governance either jointly or individually. In the specific case of this research, the analyses were carried out using the Power Relationships dimension and the categories Representativeness, Harmonic Relationships, Trust Relationships and Decision-Making Power.

\section{Results and Discussion}

\subsection{Profile of the Study Subjects}

Study subjects were 15 members from Costa Verde e Mar-SC regional tourism organization, 19 from the Hortênsias Region and 13 from the Costa das Dunas-RN Tourist center, totaling 47 interviewees, of which 27 were from the public sector, 14 from the private sector and six from the third sector.

Regarding gender, 26 were men and 21 women, with secondary to higher education, 24 of them with a bachelor's degree, 21 graduate and only two with secondary education only. Regarding the time acting as effective members of the regional tourism organizations, $25.5 \%$ had been working with some type of tourism activity for between 11 and 15 years, and in relation to their time in the function, $72.3 \%$ of the managers were in the position for less than 5 years.

\subsection{Power Relationship in Regional Tourism Organizations}

The categories representativeness, harmonic and effective relationship; trust relationship and decision-making power were analyzed based on their frequencies that determined the largest and smallest medians and modes as represented in Table 4 which represented their totality for the dimension.

Table 4. Analysis of the mean, mode and fashions of the analytical dimension 2-power relationship.

\begin{tabular}{ccccccccccccc}
\hline & C1.1 & C1.2 & C1.3 & C2.1 & C2.2 & C2.3 & C3.1 & C3.2 & C3.3 & C4.1 & C4.2 & C4.3 \\
\hline $\mathrm{N}$ & 47 & 47 & 47 & 47 & 47 & 47 & 47 & 47 & 47 & 46 & 47 & 47 \\
Mean & 4.00 & 5.00 & 4.00 & 5.00 & 5.00 & 5.00 & 5.00 & 5.00 & 5.00 & 4.00 & 4.00 & 4.00 \\
Mode & 3 & 7 & 4 & 4 & 5 & 5 & 5 & 5 & 5 & 4 & 4 & 4 \\
\hline \multicolumn{10}{c}{ Source: created by the authors (2019). }
\end{tabular}

In the general context of this dimension, it is observed that the actors understand that the regional tourism organizations have the same power in relation to votes and decisions, regardless of the sector to which they belong, but that there are not the same number of members for each sector, which can lead to decisions which are substantially favorable to particular sectors. Those who are in greater numbers may come to vote and decide in favor of their specific class or category.

The analytical dimension of power relationships based on the answers to the forms, indicates that it is an effective dimension because its modes are mostly the neutral degree of agreement, as can be seen in Table 5. 
Table 5. Multiple classification of the dimension power relationship.

\begin{tabular}{llcc}
\hline \multirow{2}{*}{ Dimension 2-Power Relationship } & \multicolumn{2}{c}{ Answers } \\
\cline { 2 - 3 } & N & Percentage \\
\hline \multirow{5}{*}{ Relationship } & 38 & $6.7 \%$ \\
& 2 Dotally Disagree (TD) & 65 & $11.5 \%$ \\
& 3 Partially Disagree (PD) & 63 & $11.2 \%$ \\
& 4 Neutral (N) & 110 & $19.5 \%$ \\
& 5 Partially Agree (PA) & 121 & $21.5 \%$ \\
& 6 Agree (A) & 87 & $15.4 \%$ \\
& 7 Totally Agree (TA) & 80 & $14.2 \%$ \\
\hline & Total & 564 & $100.0 \%$ \\
\hline
\end{tabular}

The multiple classification of the power relationship dimension brings the largest number of replies of partially agree (PA) with 121 indications and the smallest number with 38 to totally disagree (TD).

In the general multiple information of this dimension, the general sum to confirm that the dimension is effective, a sum of the agreement degrees with 288 indications and disagreement degree total of 166 indications, ensured that the dimension can be considered effective.

This analysis ensured accordance with the data from the answers to the forms that this dimension has the qualification of an effective dimension, since the degrees of agreement ensured that this result is obtained after its measurement compared to the degree of neutral agreement $(\mathrm{N})$, a degree that determines that the ratings below it are considered as non-effective and above it as effective.

Another important factor for the analyses was the observation of its dispersion Graph 1, which shows the behavior of the variables of this analytical dimension.

By looking at Figure 1, it can be verified that the variables C1.3 and C4.3 coming from the categories of representativeness and decision power, respectively, are located in the quadrant of the disagreement of the dispersions of the variables. The Categories 2 (Harmonic Relationship) and C3 presented all the indicators in the positive quadrant, and are very close to each other, being very similar according to the interviewees. It should be noted that the other two categories $\mathrm{C} 1$ and $\mathrm{C} 4$ presented two of three variables in the positive quadrant. After the observation of the variables of the dimension, information and actions based on the analyses of mode and median, besides the multiple classification were reinforced by the dispersion graph; the data show the effectiveness of Power Relationships.

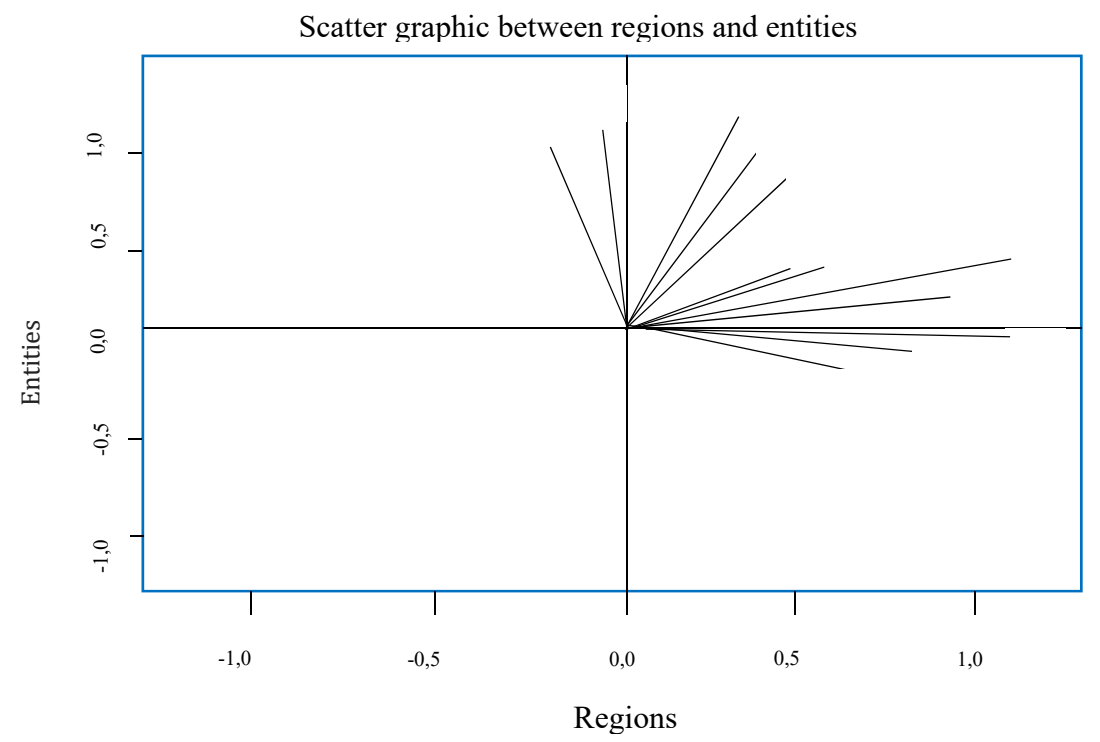

Figure 1. Relation between tourist regions and types of bodies of the analytical dimension power relationship. Source: created by the authors (2018). 
The information contained in the analyzed documents of the studied tourism regions made it possible to better understand the objectives and guidelines proposed by each regional tourism organization. These were exposed along with their management characteristics, demonstrating the functions exercised by their boards, in addition to their responsibilities. In the documents, information was sought that reflected the nature, philosophy or policy of the object being studied, and which, in this case, consisted of regulations, statutes, organizational charts, contracts, among others [36].

The documentary analysis enabled to gather information that translates the functioning of the RTOs in relation to their documents, which made it possible to understand how the dimensions related to the governance and its official documents.

The documents of the Tourism Council of the Costa Verde e Mar Region-CONVEMAR showed that its regulation and statute sought to develop the way of acting and especially its organization, determining the specific role for each actor involved. The documents revealed concern with the development of projects and their execution, but did not make clear what results it expected to achieve, and how the results would be evaluated or achieved.

The Hortênsias region has a peculiar feature. Although it is one of the largest and best destinations in Rio Grande do Sul, holding a series of public and private investments, making it a tourist destination that attracts tourists from all over Brazil, as far as their region is concerned, in terms of as a formal organization, it does not have any legal instrument, such as one establishing that it is an RTO, or a statute or regulation, but it recognizes itself as a tourist region.

The documents of the Costa das Dunas Tourist Center are consistent, since they present the attributions of its members, as well as the constitution of its RTO management. This resulted in the RTO being legally functional in terms of its organization, since, in addition to its decree and regulation, it uses a regulation that is a guiding line of what should be done at the center.

The dimension power relationship, was considered effective in the region, which, in spite of having no decree or law, has an internal regulation that indicates a relation with parity between its members, thus enabling the relations between to be dialogued and that its activities are carried out and executed by its members, divided into well-defined boards.

The dimension power relationship was considered effective because the documents pointed out how this relation should occur, with no power being privileged to the detriment of another. The documents brought content that listed how this relationship would be handled so that the members of the RTO walked together towards the joint development of the tourist region.

Bardin's content analysis [35] was one of the bases to carry out the analyses of the data obtained at the moment of the application of the forms, since the oral information of the interviewees was collected for the qualitative analysis at that time, in a natural way. The classifications of the analysis categories obtained with the use of content analysis made it possible to understand whether they were considered as effective or ineffective, as shown in Table 6.

Table 6. Classifications of the analysis categories using oral information from Regional Tourism Organizations' (RTOs') actors.

\begin{tabular}{lll}
\hline & \multicolumn{1}{c}{ Categories of Analyses } & Classifications of Categories \\
\hline 1. & Representativeness between public, private and third sectors & Effective \\
\hline 2. & Harmonic and effective relationships among private and public actors of the RTO & Effective \\
\hline 3. & Trust relationship among members of the RTOs & Effective \\
\hline 4. & Decision-making power in relation to actions of the RTO & Effective \\
\hline
\end{tabular}

Source: created by the authors (2019).

The classification of the analysis categories in relation to regional tourism organizations based on the oral information from the interviewees of the forms showed that all the categories of the dimension were considered effective. 
The common discourse during the interviews is that power relationships are essential for the management of regional tourism organizations, since it should be taken into account that they have parity not only in terms of making decisions for those involved in the RTO, but also of all those who are directly or indirectly engaged in tourism activities. Relations involving powers and sectors such as the public, private and third sectors are those that foster tourism in the regions.

\section{Data Cross Section and Theoretical Implications}

Table 6 shows the analytical dimensions with their respective categories of analysis, the variables of the forms, the classification in relation to the analysis of the documents of the regions, as well as the forms' answers, the oral information of the interviewees, and the subsequent general classification after the sum of all analyses. This information was the data obtained during the research process and the data collection, later manifested in the results of these analyses of the study.

Table 7 presents the information acquired with the analyses of the study data carried out in the studied regional tourism organizations, bringing the three perspectives of analysis. These analyses revealed the results seen in the analytical dimensions as the main element for the construction of the model.

Table 7. Analyses of the RTOs based on the quantitative, analyses.

\begin{tabular}{|c|c|c|c|c|}
\hline \multirow[b]{2}{*}{$\begin{array}{l}\text { Analytical } \\
\text { Dimension }\end{array}$} & \multirow[b]{2}{*}{ Categories of Analysis } & \multicolumn{3}{|c|}{ Classification of Analysis } \\
\hline & & $\begin{array}{c}\text { Forms } \\
\text { (Quantitative) }\end{array}$ & $\begin{array}{c}\text { Laws/Decrees, } \\
\text { Regulations and } \\
\text { Statutes } \\
\text { (Documentary) }\end{array}$ & $\begin{array}{c}\text { Oral Information } \\
\text { (Qualitative) }\end{array}$ \\
\hline \multirow{4}{*}{$\begin{array}{c}\text { Power } \\
\text { Relationship }\end{array}$} & $\begin{array}{l}\text { 1. Representativeness of public, } \\
\text { private and third sectors in } \\
\text { regional tourism organizations }\end{array}$ & \multirow{4}{*}{ Effective } & \multirow{4}{*}{ Effective } & \multirow{4}{*}{ Effective } \\
\hline & $\begin{array}{l}\text { 2. Harmonic and effective } \\
\text { relationships among public and } \\
\text { private actors of regional tourism } \\
\text { organizations }\end{array}$ & & & \\
\hline & $\begin{array}{l}\text { 3. Trust relationship among the } \\
\text { members of regional tourism } \\
\text { organizations }\end{array}$ & & & \\
\hline & $\begin{array}{l}\text { 4. Decision-making power in } \\
\text { proposals and in the validation of } \\
\text { actions in regional tourism } \\
\text { organizations }\end{array}$ & & & \\
\hline
\end{tabular}

The power relationship dimension involves its actors directly in the activities carried out by regional tourism organizations, from their planning up to their evaluation and monitoring. The power relationship must be perceived by the actors in a balanced way, not in the sense of numbers of entities that belong. Different numbers of member entities may exist in a regional tourism organization, but it should be understood and made clear that regional tourism organizations need actors who can act in management in a significant and equal way.

The answers of the members of regional tourism organizations reflect the governance models of Brazil, based on the proposition of the MTur, which encouraged tourist regions to operate together. Such action was an attempt to avoid favoring only one sector, whether public or private, and to construct a shared management practice, in which all stakeholders have the same powers in the decisions made by regional tourism organizations.

In practice, the discourse has more diverse paths, because, when RTOs deal with power relationships, the sectors often overlap, either through a more frequent and responsible performance, or merely when enjoying what has been achieved, without contributing to the management and 
organization of the RTO. However, the tourist regions of this study have demonstrated that they seek joint work, whether it is in the creation, execution or assessment of actions that will contribute to the development of tourism in the region. The classifications that are seen in the regional tourism organizations are based on the evaluation of each dimension of analysis and its categories, in order to identify the composition and operation of RTOs, and in order to understand how the dimensions are classified. From this classification and based on the results of the analyses, measures should be taken that are relevant to every situation of the RTO.

The dimension of the organization classified as effective, leads to recognize a consolidated regional management, since it already has a positive result, adding possibilities to support the development of the region. It also enables the RTO to continue to achieve favorable results in terms of its management, through planning, actions and evaluations.

The answers from members of regional tourism governance on the power relations dimension reflect Brazil's governance models. This process is the result of the Mtur proposal, which induced the tourist regions to act together, not favoring only one sector, public or private, but to constitute themselves with shared management exercises, in which all actors might have the same powers in the decisions taken by the regional tourism governances.

In practice, the discourse has more diverse paths, therefore, when the governances deal with the power relations, one sector overlaps with another, as a result of its more frequent and responsible performance. Others only enjoy what has been achieved, without contributing to the management and organization of governance. However, the tourist regions of the CVM, RH and PCD have demonstrated that in this aspect they seek to act jointly, either in the elaboration, or execution or assessment of actions that might contribute to the development of tourism in the region.

This discussion refers to what members of governance perceive clearly and objectively about the management and administrative aspects of the organization that they belong to. This way, aspects relevant to what was suggested were pointed out.

Despite being considered effective in relation to power relationship, its actions must be continually improved in order to solve possible problems that may occur, and to create new processes and institutional arrangements that add increasingly measurable values for the full consolidation of the regional management.

\section{Conclusions}

The results made it possible to understand, in an analytical way, how regional tourism organizations behave in relation to power relationships. In this sense, the objectives proposed in this research could be achieved by transposing theory to practical application, since the understanding of the power relationship among the members of the RTO was presented in a clear and precise way.

The results of the analyses indicated that the RTOs effectively manage their conflicts of interest, even if not all the RTOs studied had documents with indications on how to deal with the responsibilities of each sector. There was, though, evidence in the documents that the decisions of members have the same significance, whether in relation to decisions or executions of activities related to the RTOs' actors.

The theme of this dimension can be considered relevant since it enables to understand that the decisions on the activities to be developed for the development of the region are carried out jointly rather than attributing to members hierarchical powers, and perceive representatives as entitled to the same decision-making powers on matters inherent to the RTO.

The intention of this research was to contribute not only to the academy through science and applied research, but also to provide the tourist regions with a methodological contribution to understand the management and organization of their RTO, whose applicability in the actions carried out by them may be feasible, plausible and usable.

In this sense, the research presents the principles that should guide the management of an RTO, especially conflicts, antagonisms and harmonization of power relations which are intrinsic to the regional governance process. Considering that the RTOs in Brazil follow the only legal and political 
principle stemming from the national guidelines, this research can be replicated to other Brazilian regions, provided that their specificities are acknowledged. Brazil, due to its size, socio-cultural and economic diversity, provides an excellent experiment to test methodologies and develop new proposals. Thus, from a consistent theoretical basis in particular by Beaumont and Dredge [14], Vera-Rebollo [12], Pechalaner, Raich and Herntrei [26], Nóbrega [17], Tomio and Schimidt [20] and Arnhold Junior [37] a methodology was developed and applied that presents a matrix with variables and categories that assess the power relations in a tourist destination. This contribution gains even more value because it was applied on a regional scale. From the complexity of the regional perspective, the research brought the concept of Tourism Governance to base its proposal on, developing the research in three regions with very different tourist contexts.

The limitations of the study are linked to the sample size, because when applying the forms to the managers, some of them were not prepared to answer for different reasons, either because of lack of time, or because they did not trust surveys, because no feedback on results are provided, or even because they believe that their answers can harm their functions.

The suggestions for future research are mainly in relation to data collection, since research carried out with members of management are difficult to schedule, so it is believed that new studies using forms or questionnaires with fewer variables, and which can be applied during meetings could provide a favorable environment to achieve the expected results.

Author Contributions: Conceptualization, C.C.C. and F.A.D.A.; methodology, C.C.C., F.A.D.A. and S.J.G.d.A.; formal analysis, C.C.C., F.A.D.A. and S.J.G.d.A.; investigation, C.C.C.; resources, C.C.C., F.A.D.A. and S.J.G.d.A.; data curation, C.C.C., F.A.D.A. and S.J.G.d.A.; writing-original draft preparation, C.C.C.; writing-review and editing, C.C.C., F.A.D.A. and S.J.G.d.A.; supervision, F.A.D.A.; project administration, S.J.G.d.A.; funding acquisition, F.A.D.A.

Funding: Research funded by Coordenação de Aperfeiçoamento de Pessoal de Nível Superior | Conselho Nacional de Desenvolvimento Científico e Tecnológico.

Conflicts of Interest: The authors declare no conflict of interest.

\section{References}

1. Conceição, C.C. Modelo Analítico de Governança Regional de Turismo-MAGRET; UNIVALI: Balneário Camboriú, Brazil, 2018.

2. Ahrens, J. Governance in the Process of Economic Transformation; Draft Version; Private University of Applied Sciences Goettingen: Goettingen, Germany, April 2006.

3. De Araújo, M.N.F.; Simonian, L.T.L. Governança ambiental e turismo: A participação de atores no Parque Nacional Tortugueiro, Costa Rica. PASOS 2016, 14, 319-334. [CrossRef]

4. Bramwell, B.; Lane, B. Critical research on the governance of tourism and sustainability. J. Sustain. Tour. 2011, 19, 411-421. [CrossRef]

5. Oliveira, B.D. Governança na regionalização do turismo: Uma análise exploratória da região turística do litoral do Paraná/Brasil; Seminário da Associação Nacional de Pesquisa e Pós-Graduação em Turismo; Universidade Estadual do Ceará: Fortaleza, Brazil, 2014; pp. 1-18.

6. De Oliveira, A.G.; Pisa, B.J. IGovP: Índice de avaliação da governança pública-Instrumento de planejamento do Estado e de controle social pelo cidadão. Rev. Adm. Pública 2015, 49, 1263-1290. [CrossRef]

7. Trentin, F. Governança turística em destinos brasileiros: Comparação entre Armação dos Búzios/RJ, Paraty/RJ e Bonito/MS. PASOS 2016, 14, 645-658. [CrossRef]

8. Olsson, G. Poder Político e Sociedade Internacional Contemporânea: Governança Global Com e Sem Governo e Seus Desafios e Possibilidades; Unijuí: Ijuí, Brazil, 2007.

9. Rhodes, R. Understanding governance: Ten years on. Organ. Stud. 1997, 28, 43-67. [CrossRef]

10. Kooiman, J. Governing as Governance; Sage: Los Angeles, CA, USA, 2003.

11. Cassiolato, J.E.; Lastres, H.M.M. (Eds.) O foco em arranjos produtivos e inovativos locais de micro e pequenas empresas. In Pequena Empresa: Cooperação e Desenvolvimento Local; Relume Dumará: Rio de Janeiro, Brazil, 2003; pp. 21-34. 
12. Palomeque, F.L.; Gómez, M.M.; Clavé, S.A.; Vera-Rebollo, J.F. Análisis Territorial Del Turismo y Planificación de Destinos Turísticos; Tirant lo Blanch: Valencia, Brazil, 2011.

13. Costa, S.R.; Carvalho, C.M.B. Instância de governança regional: Uma perspectiva para o desenvolvimento turístico do polo São Luís. Cad. Pesqui. 2004, 21, 73-87. [CrossRef]

14. Beaumont, N.; Dredge, D. Local tourism governance: A comparison of three network approaches. J. Sustain. Tour. 2010, 18, 7-28. [CrossRef]

15. Gorni, P.M.; Dreher, M.T.; Machado, D.D.P.N. Parceria e cooperação intersetorial em uma organização do terceiro setor: O caso do Balneário Camboriú Com Vida Convention \& Visitors Bureau. Rev. Tur. Visão Ação 2009, 11, 263-279.

16. Dreher, M.T.; Salini, T.S. Governança e políticas públicas de turismo em Gaspar, Santa Catarina. In Proceedings of the Seminário de Pesquisa em Turismo do Mercosul, Caxias do Sul, Brazil, 9-10 July 2010.

17. Nóbrega, W.R.M. Turismo e Politicas Públicas na Amazônia Brasileira: Instâncias de Governança e Desenvolvimento Nos Municípios de Santarém e Belterra, Oeste do Estado do Pará; UFPA: Belém, Brazil, 2012.

18. Araujo, L.M.; Dredge, D. Tourism development, policy and planning in Brazil. In Tourism in Brazil: Environment, Management and Segments; Lohmann, G., Dredge, D., Eds.; Routledge: New York, NY, USA, 2012; pp. 17-29.

19. Lefebvre, M. Social security and early retirement: The relationship between worders, firms and governments. Ann. Public Coop. Econ. 2013, 84, 43-61. [CrossRef]

20. Tomio, M.; Schimidt, C.M. Governança e ações coletivas no turismo regional: a experiência dos empreendedores da região oeste do Paraná. Rev. Tur. Visão Ação Eletrônica 2014, 16, 710-739. [CrossRef]

21. Valente, F.; Dredge, D.; Lohmann, G. Leadership and governance in regional Tourism. J. Destin. Mark. Manag. 2015, 4, 127-136. [CrossRef]

22. Zahra, A.L. Rethinking regional tourism governance: The principle of subsidiarity. J. Sustain. Tour. 2011, 19, 535-552. [CrossRef]

23. Cunha, A.J.; Mazaro, R.M. Princípios da governança aplicados à gestão de destinos turísticos: Uma análise propositiva no Polo Costa das Dunas. In Proceedings of the VIII Seminário da Associação Nacional Pesquisa e Pós-Graduação em Turismo, Balneário Camboriú, Brazil, 2-4 October 2011.

24. Meneghel, L.M.; Tomazzoni, E.L. A comunicação e a integração dos atores do turismo regional: O caso do observatório de turismo e cultura da Serra Gaúcha (OBSERVATUR). Rev. Tur. Visão Ação Eletrônica 2012, 14, 246-260.

25. Rovere, M. Redes En Salud: Un Nuevo Paradigma Para el Abordaje de las Organizaciones y la Comunidade Rosario; Secretaría de Salud Pública/AMR, Instituto Lazarte: Rosario, Argentina, 1999.

26. Pechlaner, H.; Raich, F.; Herntrei, M. Destination management organizations a interface between destination governance and corporate governance. Int. J. Tour. Hosp. Res. 2011, 23, 151-168. [CrossRef]

27. Virginio, D.F.; Delgado, A.K.C.; Fortes, L. Microfísica do poder no turismo: Reflexões sobre as relações de poder no conselho estadual de turismo do RN. Cad. Virtual Tur. (UFRJ) 2011, 11, 267-281.

28. Duran, C. Governance for the Tourism Sector and Its Measurement; Issue Paper Series; UNWTO Statistics and TSA: Madrid, Spain, 2013.

29. Silva, J.M.D. Políticas e Programas de Turismo no Rio Grande do Norte: Reflexões e Propostas; UECE: Fortaleza, Brazil, 2014.

30. Luz, A.T.M.; Pagliarussi, M.S.; Teixeira, A.M.C.; Baptista, E.C. Uma investigação sobre a relação entre atribuições em causa própria e governança corporativa. Braz. Bus. Rev. 2009, 6, 191-208.

31. Rover, O.J. Redes de Poder e Governança Local: Análise de Gestão Político-Administrativa em Três Fóruns de Desenvolvimento com Atuação na Região Oeste de Santa Catarina/Brasil; Universidade Federal do Rio Grande do Sul (UFRGS): Porto Alegre, Brazil, 2007.

32. Gelman, A.; Hill, J. Data Analysis Using Regression and Multilevel/Hierarchial Models; Cambridge University Press: Cambridge, UK, 2006.

33. Tomazzoni, E. Identificação dos elementos do desenvolvimento regional com base em análise de um destino turístico: A Região das Hortênsias (Serra Gaúcha). Rev. Acadêmica Obs. Inovação Tur. 2008, 3, 5-6. [CrossRef]

34. Crespo, A.A. Estatística Fácil, 19th ed.; Saraiva: São Paulo, Brazil, 2009.

35. Bardin, L. Análise de Conteúdo; Edições 70: Lisboa, Portugal, 1977. 
36. Michel, M.H. Metodologia e Pesquisa Científica Em Ciências Sociais, 2nd ed.; Atlas: São Paulo, Brazil, 2009.

37. Arnhold, M., Jr. Governança Regional de Turismo: Uma Proposta de Avaliação da Governança Turística da Percepção de Seus Atores; Universidade do Vale do Itajaí (UNIVALI): Balneário Camboriú, Brazil, 2017.

(C) 2019 by the authors. Licensee MDPI, Basel, Switzerland. This article is an open access article distributed under the terms and conditions of the Creative Commons Attribution (CC BY) license (http://creativecommons.org/licenses/by/4.0/). 